\title{
Black Male Teachers, White Education Spaces: Troubling School Practices of Othering and Surveillance
}

\author{
Christine Callender \\ UCL, Institute of Education
}

\begin{abstract}
The absence of male teachers in primary schools has been an ongoing concern for policymakers and schools in the UK, USA, Canada and Australia and as schools have become more ethnically diverse so have concerns that the teacher workforce should reflect the communities it serves. Pre-service teacher training plays a critical role in this aim by identifying, recruiting, retaining and training those who demonstrate potential to become teachers in English primary schools. As one of a few studies to explore the racialised and gendered experiences of black male teachers in England, I adopt the use of Critical Race Theory (CRT) to examine how black male teachers are characterised and constructed in white education spaces. Drawing on a larger study, this paper utilises race as a social construct and counternarrative, key precepts of $C R T$, to draw attention to processes of exclusion, othering and surveillance through the experience of David (the main character). Interview and documentary data illuminate institutional processes of overt and covert racism as well as racialised and gendered stereotyping. David's story reveals how his voice is muted as it is woven into processes of othering, hyper-surveillance and disciplinary power.
\end{abstract}

\section{Keywords:}

Black male teachers, Critical Race Theory, surveillance, othering, counter-storytelling, racism

\section{Introduction}

This paper aims to understand the racialised and gendered experiences of black male teachers as they transition from teacher education into the early stages of their careers. It starts from the position that the teacher workforce in England should reflect the communities it serves. Black teachers comprise $3.6 \%$ of the school workforce population in England, (DfE, 2018), of those who self-identify as black, $2.7 \%$ comprise class teachers, assistant and deputy heads and head teachers). There is a significantly lower proportion of Black and Minority Ethnic (BME) staff than the BME school population. Almost one third of pupils in state maintained primary schools and just over a quarter of the pupils in state maintained secondary schools are BME (op.cit.). A similar pattern is found in the US where the African American teacher population is marginally more representative at $7 \%$, and African American males comprise just $2 \%$ of the overall count (Lewis, 2006; US Department of Education, 2016).

BME teachers are geographically and organisationally segmented. Located in areas of high ethnic diversity there is a preponderance of BME teachers in schools that serve 
deprived communities. Additionally, black teachers also occupy fewer senior positions (Steel, 2015) and are found in greater numbers in Academy schools (DfE, 2011a). Despite modest increases in BME teaching staff over the years, this is vastly surpassed by the growth in BME student populations. In fact, current estimations suggest that an additional 68,000 BME teachers are required to reflect England's BME school population (Rhodes, 2017) and assuming that recruitment remained static, it would take 16 years to achieve a teacher workforce that resembles the communities it serves.

Amongst long-standing issues of representation, career advancement and leadership, policy makers and politicians alike have lamented over the low numbers of black male teachers in schools and in positions of leadership (Miller \& Callender, 2017). The black male teacher gap is primarily situated within a discourse of representation, particularly as role models (Maylor, 2009). There have been few attempts to incorporate black men's perspectives of their education or their views as teachers. Importantly, research does not examine the intersection of race and gender. The de facto story used to identify, prioritise and address the issues relating to men in teaching does not speak explicitly to BME men and thus obscures and silences their experience. This article utilises counternarrative to illuminate institutional processes of overt and covert racism as well as racialised and gendered stereotyping to understand the experiences of black male teachers. Before examining the issues, we turn to a review of the literature within the broad discussion of research on BME teachers.

\section{Literature review}

International studies on black teachers are primarily located in the USA and Canada (Lewis \& Toldson, 2013). These studies have examined various factors including motivation to teach (Griffin \& Tackie, 2017); recruitment and representation (D'amico, Pawlewicz, Earley \& McGeehan (2017); access to promotion and continuing professional development (Kohli, 2018), the efficacy of bespoke recruitment programmes (Ogunbawo, 2012), role modelling (Martino \& Rezai Rashti, 2012), culturally relevant pedagogies (Lynn, 2006), the experiences of black male teachers in public schools (Callender, 2018), the ways in which Black male teachers navigate their way through the inimical terrain of schools (Woodson \& Pabon, 2016) and the contradictions that arise from policies which suggest that black male teachers are wanted and needed, despite their subsequent treatment in schools (Pabon, 2016).

Regarding England, Maylor (2018: 112), has noted that 'much has been written about the underrepresentation, positioning, roles, experiences and value of black teachers in primary and secondary schools'. This body of work, however, rarely includes the perspectives of black male teachers. Notwithstanding that issues of recruitment and underrepresentation amongst BME teachers in English schools are concerning, and despite targeted recruitment drives in the 2000s where teachers from overseas were recruited to address acute teacher shortages (Miller, 2018), underrepresentation of black teachers in England continues to be of longstanding policy concern (Hinds, 2019). Three themes emerge from UK literature on BME teachers: recruitment, representation and retention. These are considered below.

Successive teacher recruitment policies have failed to significantly increase numbers of BME teachers in England's schools and, according to Blair (1994: 277), the area of recruitment may be a useful starting point from which to examine this phenomenon. 
Writing on the impact of neo-liberal market ideologies, she contends that changes to curriculum which foreground notions of Britishness and of 'nation' influence constructions of the "ideal" teacher. Within this construction skin colour becomes 'a significant marker of difference and hence of differential treatment' which creates and reproduces nationalistic ideas of 'us' and 'them'. Blair contends that these discourses position black teachers differently from white teachers and, that market ideologies, in turn, may underpin black teachers' desirability to schools. Blair rejects the conceptualisation of black teachers as the 'professional ethnic - those who are 'naturally equipped to manage, minister to, and deal with issues relating to black students' (pg. 285) and these observations may hold resonance with the experiences of black male teachers particularly given the racist constructions of black males as "aggressive", "troublemakers" and "lacking discipline". As (Maylor, 2018) points out stereotypical assumptions of black males inadvertently adds to concern about the undesirability of black males in schools.

The BME teacher workforce in England is impacted on because of low retention and higher than average attrition rates (Allen, Bibby, Parameshwaran \& Nye, 2016) and overt racism in schools. For more experienced teachers, the picture is similarly bleak. The National Education Union (2019) for example, reports that black teachers in England are disproportionately represented in capability procedures. They also experience 'everyday racism in schools and colleges, discrimination, harassment, ostracism, lack of pay progression, and BME teachers being held back from promotion' (NASUWT \& Runnymede Trust, 2017: 6). Haque and Elliot (2017: 43) point out that 'institutional racism - often manifested in subtle and covert 'microaggressions' by senior staff - still plays a key part in the barriers to career progression for Black teachers in many British primary and secondary schools.

Thomas \& Warren (2017: p. 87) explain that the condition under which black males teach is admirable yet "troubling and precarious" and note that their voices are muted as they employ silence as a coping mechanism - a strategy used to avoid confrontation or misunderstanding. Other studies too, have identified strategies which male teachers use to navigate and survive in schools. "Identity bruising", a form of "knock-back" when one's sense of identity is ascribed but not necessarily accepted or understood is a feature of male teachers' experiences in primary schools and result in them complying with, resisting or developing strategies as markers of masculinity (Foster \& Newman, 2005). Similarly (Callender, 2018) argues that black male teachers':

'identities are affected by negative assumptions and stereotypes which may impact on judgements made about their positionality in schools. Notwithstanding, these men adopt a range of strategies to counter negative or stereotypical perceptions and deploy agentic strategies to foreground their teacher identity and the contributions they make to learning and teaching.'

The 'othering' and isolation experienced by black male teachers in schools runs alongside arguments which assert an assumption that they are ideal disciplinarians of black boys. This logic assumes that black teachers possess knowledge, cultural skills and attributes to improve the outcomes of black boys and supports the rationale that their 'rugged manhood' is part of an 'implicit common-sense narrative' (Brown, 2012) which suggests that any black male teacher, regardless of background, could be a successful teacher of black boys (see also Maylor, 2009). This view, however, ignores the pedagogical demands of teaching. King (2016) likens this phenomenon to an 'invisible tax' ascribed to black male teachers constituting the adoption of the additional 
roles of 'other father' (Lynn, 2002) role model (Martino and Rezai Rashti, 2012), mentor (Jackson, Sealy-Ruiz \& Watson, 2014) and de facto disciplinarian (Brockenbrough, 2015). Pabon (2016) also alludes to a contradictory discourse, a "double-talk" surrounding black male teachers in schools. Here the pervasiveness of the implicit common-sense narrative overrides the professional development needs of male black teachers leading to a situation where "even in the midst of being conceptualized as Black Supermen [black males] are under supported and being pushed out of the very schools that claim to need them so much" (p. 934).

As Yancy (2014: 3-4) asserts, classrooms are places where black males' arrival 'is rendered hyper-visible because of how various social spaces - the classroom being one - are constituted as an enveloping White racial integument that holds together White bodies and that installs those White bodies as familiar and "familial"' a social skin that calls to those bodies as wanted and as desirable'. Moreover, 'schools often operate as spaces where the realities of race and racism go undiscussed' Stovall, 2006: 232). For black male teachers this requires careful navigation of their identities leading to them finding "themselves in perpetual negotiation as they seek to reconcile their individual lived experiences with prescribed societal expectations and limitations" (Howard, 2014: 40).

Thus, when black males enter schools they are simultaneously faced with the dual task of socialisation into their professional roles as teachers, the organisational cultures of the school as well as having to navigate the processes of assimilation in order to become part of the school community. The juxtaposition of managing the teacher role and assimilation to the school structures while nurturing their identities as black men within settings where they are in the minority, poses challenges for this group in navigating the cultures of school effectively. Their success (or lack thereof) is contingent upon a context where they are woefully underrepresented.

\section{Critical Race Theory}

The study draws on Critical Race Theory (CRT), a body of scholarship which emerged from Critical Legal Studies in the USA and is used to explore and challenge the prevalence of racial inequality in society. From its inception CRT has been deployed as a "weapon of struggle" (Stovall, 2005) and, a means of addressing the concerns of minoritized groups. CRT contends that race and racism are not abnormal and are inextricably linked to power relations. It seeks to expose the maintenance of racial inequality which is maintained through the operation of structures and assumptions that appear normal and unremarkable. At the core of CRT is the contention that racism is endemic, institutional and systemic (Solórzano \& Delgado Bernal, 2001). CRT critically examines master (or dominant) narratives that are reproduced and counternarratives that are silenced. Limitations of space do not allow for an expansive discussion of CRT here, however, the work of Crenshaw, Gotanda, Peller \& Thomas (1995); Delgado and Stefancic (2001) in the US and Gillborn (2005; 2006) and Hylton (2005) in the UK provide more detailed accounts.

CRT's foray into the field of education can be traced to the seminal work of LadsonBillings \& Tate (1995). This early articulation of CRT scholarship in education laid the foundation upon which its scholarship has developed on both sides of the Atlantic and 
elsewhere. Originally framed within five central tenets: the centrality and intersectionality of race and racism; the challenge to dominant ideology; valuing experiential knowledge; and the interdisciplinary perspective, CRT's allure to race conscious scholarship lies in the power of its analytical framework and in its capacity to address endemic racism in society and its unapologetic stance on the centrality of race as a unit of social analysis (Leonardo, 2009). CRT's use in the UK has grown in recent years (Warmington, 2019) and although the histories of race and racism in the UK and USA are different, its applicability to the examination of racial hierarchies is pertinent to both contexts.

As a field of scholarship, CRT is relatively young and its methodological and analytical power has been used to examine a range of issues across all phases of education. Ledesma \& Calderón (2015: 206) for instance, note that CRT has become an 'increasingly permanent fixture' of education scholarship providing researchers with a 'toolkit'. Inasmuch as there has been a plethora of work in the field, scholars have cautioned those working within the field to constantly remain conversant with and vigilant to the fidelity of its historical roots in Critical Legal Studies (CLS), in the work of scholars, and the disciplines that laid the foundation upon which CRT is built (Howard \& Navarro, 2016; Dixson \& Anderson, 2018). CRTs emergence from a critique of racialised injustice in the US legal system and its ability to reveal how racism is structurally embedded in the legal framework and structures such as courts mirrors concerns that have evolved in the educational outcomes of African American pupils patterns of underperformance which have been mirrored in the poor attainment levels of BME pupils in English schools. Since the publication of Ladson-Billings \& Tate's (1995) seminal text, the growth of CRT scholarship 'has not necessarily followed a clear path or resulted in a well-defined body of scholarship in education' (Dixson \& Anderson, 2018:122). Writing on CRT in England, Warmington (2019) describes CRT as a 'significant intellectual force among anti-racist scholars and activists' yet it is instructive to note that critiques of CRT emanate from within and outside of the discipline. Darder and Torres (2004, cited in Ledesma \& Calderón, 2015) denounce CRT on the basis that it does not incorporate a 'substantive critique of capitalism' and that 'the use of 'race' itself has been elevated to a theoretical construct, despite the fact that the concept of 'race' itself has remained under-theorized' (p. 207). More recently, Ladson-Billings (2013:44) warned against grabbing "hold of CRT as a "sexy", "trendy", "new" thing'. Through the presentation of a CRT "anti-chronicle", she reminds scholars of what CRT is not and of the importance of maintaining quality in CRT work.

CRT has attracted criticism, leading Ledesma \& Calderón (2015) to claim that 'because CRT has proven to be hyper-scrutinized, it behoves current and aspiring Critical Race Scholars to hold each other accountable' (p. 207). Similarly, Carbado, a legal scholar (2011, cited in Dixson \& Anderson, 2018) puts forward the view that there are a number of characteristics of CRT and proposes that these are used as 'boundaries' around which theory may be developed. Pointing to CRT's development, Carbado observes that identifying oneself as a CRT scholar is to invite the question: 'critical what what?' warning that 'a theory without clear boundaries is hard to mobilize and describe as a theory' (op,cit). These are important questions and no doubt will continue to be debated as CRT develops in the future. Nonetheless, a central concern for CRT, and how it evolves in that future, is the extent to which it has been able to answer the questions it was established to address. Added to this is the combination of its 'adolescent growing pains' (op cit) as it continues to grow theoretically and 
methodologically whilst at the same time addressing critical issues of inequality facing society today. As Ladson-Billings (2013) argues, 'we have an obligation to point out endemic racism that is extant in our schools, colleges and other public spaces... and we must be careful to guard this movement that is entering "its academic adolescence." We must be willing to say what critical race theory is not' ( $p .45)$.

This study draws on a key tool of CRT, counternarrative, to shed light on black male teachers' experience and to expose processes of differential racialisation, gendered and racialised subordination and the invisibility and regeneration of privilege. In this instance, counternarrative serves to reveal an alternative telling to accounts of male teacher experiences in schools and to highlight the dynamics of racialised and gendered experience in research concerning BME teachers.

\section{Storytelling and counter-narrative}

A key precept of CRT is the role of experiential knowledge and its power to present counter stories (or narratives) to the majoritarian 'master-narrative'. Counternarrative, serves to contradict and expose race neutral discourse whilst revealing how white privilege reinforces and supports unequal racial hierarchies. It argues that majoritarian discourses rely on the tacit knowledge of dominant groups but, in doing so they silence and distort the experiences of the minority. As Matsuda (1995: 63), argues, 'those who have experienced discrimination speak with a special voice to which we should listen'. In short counternarrative tells the story of those inside but who are also positioned on the outside, recognising experiential and embodied forms of knowledge as legitimate in understanding racism. Delgado (1989) considers counternarrative as 'a kind-of counter reality' experienced by those subordinated in a racialised and gendered hierarchy. The 'ingroup' creates 'stock stories' to establish and bolster a shared sense of identity, reality and to embed their superior position whilst the 'outgroup aims to subvert that ingroup reality' (pp. 2412-2413). Counternarrative thus, is a method of telling stories by those whose experiences are not often told, making it possible to understand in new and different ways and from alternate perspectives. As a methodology it aims to explore, analyse and challenge stock stories, bringing minoritized voices and alternative perspectives to the fore, with the purpose of counteracting the stories of the dominant group (Delgado, 1989).

Solórzano and Yosso (2002: 32-33) identify three types of counternarrative and/or story: personal stories or narratives; other people's stories or narratives and composite stories or narratives. Personal stories comprise autobiographical reflections set against CRT and wider socio-political analysis. Other people's stories reveal both experiences of and responses to racism and sexism. Told in the third person they provide biographical analyses of experience within institutions and in a socio-historical context. Composite stories or narratives draw on various forms of data, can be autobiographical or biographical and locate the composite character in social, historical and political contexts to discuss racism, sexism and other forms of subordination.

The creation of a counter story is informed by theoretical sensitivity, where researchers possess 'insights as well as being tuned into and able to pick up on relevant issues, events, and happenings during collection and analysis of the data' (Corbin and 
Strauss, 2015: 78). Theoretical sensitivity requires the researcher to not restrict themselves to the extant literature, their personal or professional experience but instead to question, analyse and compare the data with 'the ability to make something of these insights...' to demonstrate 'the ability to conceptualize and organize, make abstract connections, visualize and think multivarietely' (Glaser \& Holton, 2004: para 43). By combining elements of counternarrative and the current socio-political reality of schools this article aims to construct an alternative telling that is richer than the story or the reality alone.

\section{The study}

The story presented here is part of a larger research project which examines the lives and experiences of 10 black male teachers (Callender, 2018). Participants were recruited using a criterion sampling method on the basis that they self-identified as: male, from a black background and had qualified to teach in the last two years. The participants interviewed completed their training via several different qualification routes, all were in employment at the time of interview. I have selected the data of one participant David, for analysis to illuminate the power of the story telling narrative in giving voice to teachers who are muted. The story that is presented is a snapshot of David's experience. As such, it does not claim that the experiences are generalisable to all black male teachers. Rather, as the review of literature demonstrates, its intention is to reveal the complex ways in which racialised and gendered scrutiny creates and ascribes homogenising discourses to black male teacher bodies.

Participants were interviewed twice, soon after the completion of their teacher training and again in the Spring term of their first year. Interviews lasted between 45-90 minutes and, were digitally recorded, transcribed and returned to participants to check for accuracy. Whilst the interviews were guided by a loose structure the questions sought to garner details of the participants' backgrounds and school, including perspectives as male black educators; reasons for choosing teaching and experiences related to concerns raised about professional standards of behaviour. The data were the evidence base used to invoke the school's disciplinary procedure including assessment of David's capability as a teacher. It was important, therefore, to consider several factors, not least the creation, intended purpose, use and ownership of the documentary data and the ethical issues that their use presented. Whilst the data were David's property and he had given consent for their use, they had been written about him. David considered the documents as illustrative, and contingent to his experience as a teacher and the way in which he was conceptualised in the school. Significantly, they provided a tangible, discursive articulation, an evidential account, in the words of his colleagues which shed light on how he was understood and conceptualised by the school. A discussion of these documents took up a significant amount of time during the second interview and it was for this reason that they are considered integral to David's narrative. The privacy, confidentiality and anonymity of the authors, nonetheless, was a significant factor in deciding how and if the data could be utilised.

Following consultation with the university ethics committee further additional clearance was sought to include the documentary data. Because the story would provide a biographical narrative, it was shared with David to secure his agreement and for the purpose of confirming anonymity and confidentiality. Careful attention was paid to the creation of the narrative to ensure that documentary data were reported faithfully and 
in accordance with the context in which they were originally assigned. It was noted too that according rights to confidentiality and anonymity may "involve employing 'fictionalising' approaches when reporting, and where using such approaches researchers should fully explain how and why they have done so" (BERA 2018:2). The names of all participants are anonymised as are any other identifying features such as geographical location, names of places etc.

David offered several insights to how gender, race and class shaped his perception of teachers, his understanding of the schooling experiences of black boys and how these aligned with his professional role as a teacher. David's interviews thus provided an important context within which to examine othering, surveillance and exclusion which are central to the research. Gathering such data is invaluable as it not only provides a first-hand account but also provides a counter-story to the research findings on male teachers in the UK. Although David's narrative emphasises his experience of racism, it also highlights how he responds to assumptions about black males. In the narrative, David's words and phrases and the narrative of other characters are presented verbatim. David's counternarrative is presented in quote marks and the other characters in italics. Both are presented without additional comment or interpretation. The aim here is to avoid the imposition of my subjective judgement or feelings, relying instead on the narratives shared in interviews and through the documentary data. Taken together the approach ensures that there is a direct link between the original interview transcripts, documentary data and the final narrative. The themes are organised in line with those in the interview - surveillance; othering and capability/competence. These are discussed below following a brief introduction to the main character, David.

\section{David's story}

David could be considered a 'highflyer'. Born and educated in England at the age of 11 he attended a fee-paying private school on a full scholarship. After A levels he studied at a prestigious university and trained in the field of civil engineering. Considering the long-standing phenomenon of low educational outcomes for black males (Strand, 2012), as well as higher than average exclusion rates (Demie, 2019), high unemployment rates (ONS, 2019) and the small proportion of black males holding a degree or higher qualification, David's educational achievements can be described as atypical. Despite his achievements David was critical of his education, particularly at the interstitial space of race and gender. His positive experiences of primary school were overshadowed by overt racism and hostility during secondary school. He explains the 'strangeness' of attending a school where he was a racialised minority:

"I'd be on the bus with all the people l'd grown up with that we were getting off at different schools, Acorn Boys, Everglade, Hollytree - all the state schools around the area. Then l'd be on my own. Get off and go into this school and suddenly I'm kind of... one of a few. I found it very weird, it was like...strange."

Moreover, at the age of 11 David understood that the dynamic of his racialised identity rendered him hypervisible and that he challenged the school's conceptualisation of who should inhabit the school space as well as who was deemed intelligent. He reflects: 
"I went to a private secondary school. There were six black guys including me. There were only four by the time I got to year 9 . The teachers often called me stupid, but it didn't make sense... I was in the top form and I came in the top 20 for everyone who did the entrance exam. Yet, I was called stupid all the time. I was always getting called stupid..."

High levels of disciplinary scrutiny and criticism were key features of David's narrative (Gillborn, Rollock, Vincent \& Ball, 2012), and David found acceptance in sport. "If I hadn't been good at rugby it would have been a lot worse." Valorised as a talented rugby player, he was sought after to represent the school, winning several accolades for them. As he reported "I wasn't just going to do PE because I was good at it. So many black people that I grew up with, they were going towards sport. I was like, I've got a brain!"

A theme of suspicion was evident in David's narrative. At points he referred to the ways in which his academic success was viewed with scepticism where he would be required to continually 'prove' his academic performance. He said, "I used to sit on my own." David explained that he sat separately from other pupils as a matter of choice rather than design. His academic achievements were held to a higher level of evidential proof and success met with disbelief and incredulity. Watched constantly, he recalls:

"I remember the teacher used to come and stand over me during the test instead of invigilating the room. She would stand over me for the whole test. She kept accusing me of cheating."

He surmised, "I did not fit," aware that "academic ability was a problem for them" to such a degree that even though his test results were often the highest in his class, particular teachers were relentless and concerted in their efforts to disprove the veracity of his academic strengths as a justification, he thought, to place him in lower attaining classes.

Racism saturated David's experience of secondary school and his teachers made no attempt to disguise crude racism and low expectations. By year 10, his attitude had changed, "I just thought why am I doing it? Why bother because they treated me like a dunce, they were always trying to mark me down." David's parents, particularly his father, were instrumental in challenging the school, questioning racist practises and holding the teachers to account. By the time he commenced A levels his view of teachers had started to change too. Mr Shaw, a new teacher whom David described as "a really intelligent man, a genius", took an interest in him and he, in turn, "had a lot of respect" for Mr Shaw. With his passion for learning reignited David excelled at A level.

\section{'You're kind of on the outside'}

Secondary school left an indelible mark on his perception of teachers and of schools. So much so that it influenced his decision to become a primary school teacher. "At the end of the day, I've got to do this for them. I do it for my son, my brother. I see myself in the children I teach." David's narrative includes examples of inclusion and exclusion 
where he described being subjected to formal and informal monitoring. Learning environments such as university and school were spaces of institutional (and self) surveillance. For example, David's status, as one of two black males in his PGCE cohort heightened his visibility, "I'm the minority at that place. I'm noticed by the tutors because I'm the only black guy in the room." Juxtaposing his minority status against that of his peers, he remarked, "the main bulk is the white middle class and if you look at the little cliques' people have formed... little groups of white middle class." David noticed others were excluded too, "a group of Muslim women, they sit together and it's not by choice, it's not by choice."

David understood the logic of racial dynamics, he had honed these from an early age. He understood white racial knowledge and the subtleties of knowing race whilst unknowing racism (Leonardo, 2009), he understood that friendships at university were influenced by social positionings such as gender, class, age, religion and ethnicity (Read, Burke \& Crozier, 2018). Not unlike David, the Muslim women's dissonant bodies were out of place, they are set apart from the peer clique. He described the experience of the learning environment at university as exposed and segregated. $\mathrm{He}$ recalled that as the lone black male it was not unusual to be required to make regular contributions to class discussion. The expectation, however, was silent, subtle and implicit, "I don't know if they are aware, they are looking at me, like they're waiting to see my reaction. They put a question out, they then kind of look at me as if to say, you got anything to say?"

Even though he was spatially located within a wider student group he was often located outside of learning activities. David described how group tasks were often corralled, "I'm quite comfortable to be on my own, I don't need to have a group of friends around me. I'm fine. I'm not going to change myself or go out of my way to show you that I'm not what you think I am or to present myself as something which makes you feel comfortable." He rejected the idea that he had to modify aspects of his identity or take on chameleon like qualities in order to 'fit in' rather, he sought out contexts where he belonged because, a black male "you're kind of...on the outside" (Brown \& Johnson, 2014). He explained, "once the lectures are finished, I leave. I go and seek out my friends. We're like...colourful (laugh)."

Friendship with other minoritized students represented shared identity and mutual support in the overwhelmingly white Academy (Pilkington, 2014; EHRC, 2019) and a 'counterspace' where bonds with other students assisted in his ability to overcome the learning environment (Howard \& Navarro, 2016).

\section{Race, gender, (in)capability and (in)competence}

As an NQT, David commented that he was held to the higher levels of professional standards but that these expectations were not always a requirement for others. $\mathrm{He}$ was committed to becoming an outstanding teacher and wanted to ensure that children had an experience unlike that of his own. He had chosen to work in a school with a rich ethnic and cultural mix and thought it important that the children saw him as 'authentic', someone who not only understood but had lived their experience. Although most of the children in his class did well, the attainment of black boys was poor, stubbornly static and the rate of suspension and internal exclusion was above 
average. David was recruited to the school as he was considered a good role model. He was the only black male teacher in the school, with other BME staff in support roles. He describes a post-lesson conversation which took place in the staffroom with his mentor Angela:

You have a very positive relationship with your class, and it looked like the children were having fun. Your Teaching Assistant was well deployed and supported the children well. I loved the fact that you call the children Professor, it makes them feel special. I really do like the way you interact with the children but, be careful not to appear too relaxed and informal. You should maintain boundaries.

David explained how he listened carefully and took notes. He was a little concerned by the suggestion that he was 'relaxed and informal' particularly considering the positive feedback he had received commenting on the strong rapport and good relationships he had with the class. He noted too that this was contrary to earlier feedback about his strong skills in classroom behaviour and management:

Have all the children been challenged in the lesson?

Thinking about a previous situation where he had given an opinion and subsequently been informed that he had been rude. he took the decision to listen and use silence as a strategy to deflect further negative commentary regarding his interactions with colleagues. However, it also highlighted the power dynamic in the conversation and his positioning in the school:

You care deeply for the children but, sometimes learning must be uncomfortable. I don't think that the lesson was pitched at the highest level for all children to make good progress'... David, you need to understand that the purpose of feedback is to get your views of the lesson and to know your thoughts, in that way you can move forward effectively.

He described feelings of deflation as he realised that the lesson may not have gone as he had imagined. Recognising the need for further guidance he commented, "Tell me what to do and I'll do it. I always do what you tell me. I just want to pass my NQT year."

It is very difficult to have a conversation if you refuse to engage in professional dialogue'. 'It looks as if the advice is going in one ear and out of the other. Do you understand?

David disclosed that his feelings of failure and embarrassment were compounded by the fact that Claire (his parallel teacher) was seated nearby. He felt that he had let himself and Claire down. His strategy of silence (Thomas \& Warren, 2017) had kept him out of trouble so far. He had avoided conflict, but silence had rendered him impotent. He was reminded of secondary school. Wildman and Davis (1995: 885) argue that 'silence may result from the appreciation of quiet or may signify the operation of intense mental processes. Silence may also arise from oppression or fear. Whatever the reason for silence, its presence means the absence of verbal criticism. What we do not say, what we do not talk about, maintains the status quo'. In short, silence can re-enact systems of power and privilege resulting in the muting of subordinated voices. 


\section{'It's like magnets'}

David explained that othering was a staple ingredient of his professional life. As he put it, 'the plight of the black man in teaching is bad'. Describing racism as an unseen yet powerful force, his metaphor below resonated strongly:

"It's like when you put magnets together. There's an invisible... you feel it. You're trying to talk to them and there's something. They've got some kind of barrier."

David's narrative contained many examples of the imperceptibility of racialised othering. He could not always name it, but he felt it deeply, the invisible force to which he referred was powerful in effect. Following the discussion with Angela he was informed that he would be required to meet with the Headteacher, Zarah. Here he was advised that he was failing to meet the Teachers' Standards, the professional requirements of all teachers in England. Silence had prompted a complaint. $\mathrm{He}$ described Zarah entering the room and announcing:

I would like you to reflect on this meeting and I will arrange a time with you to discuss what has gone on here today....

He questioned whether he had misunderstood the 'unspoken rules of engagement' (Rollock, 2012).

David described how, in preparation for the meeting with Zarah he had requested copies of reports written about him as these were the basis of the complaint. On receipt of the documents he explained that he was presented with a version of himself that was unrecognisable, and which challenged the view of the teacher he aspired to be. $\mathrm{He}$ described the impact of the ascribed characteristics of a psychologically unwell and angry black man. Claire in her report had written:

I think he's a bit paranoid and our relationship is really beginning to suffer.

She had noted too, David's concern that he had been labelled as 'aggressive' (Howard, 2014; Maylor, 2018). To humour Claire, he described how a throwaway comment, "Watch out, there's an aggressive black man in here" he had said as a joke metamorphosed into concerns about his psychological well-being. He recognised Claire's comment:

He's giving me the silent treatment or responding with one-word answers

He did not comprehend how his silence had been misconstrued or how it could be conceived as disengaging from professional dialogue.

He talked about how stereotyped descriptors ascribed to black boys were also used to characterise him and his demeanour. David credited Angela with "oversight of my professional development", she was significant to his success as a beginner teacher and integral to providing essential early career development support and guidance. Her role in validating his teaching capability appeared in excess to normative expectations in the school. David described their relationship as "friendly but professional" and spoke of his surprise at the tone and content of Angela's comments: 
I was really annoyed by his casual approach in the meeting today. He was slouched on the chair and deliberately refused to engage. He refused to make eye contact, acknowledged all of my comments and couldn't be bothered to speak. Instead, all I got were nods, murmurs, strained facial expressions and non-committal body language. He was really abrupt and hostile. I found the whole thing intimidating due to his lack of interest and defiance.

The behaviours were the ones that he had worked hard to eradicate in his class and had resulted in fewer black boys receiving internal exclusions. David mused "most of the teachers would bring in mainly black boys [to my classroom] because they responded to me. They would come in and ask, what strategy do you employ? There's no strategy. I'm talking to them and they can relate to me. That was it." He explained that his reticence to speak constructed a framing in the report which had presented him unfavourably and as lacking the necessary professional attributes. By implication they questioned whether he possessed appropriate interpersonal skills to undertake the role of a teacher:

He just would not participate. His silence was intimidating and when I told him so, he was more aggressive. In all my 13 years mentoring NQTs in this school and in the borough, l've never had one like him. In the end I just had to leave the room. I'm afraid I just can't continue to mentor him after today.

David spoke of the way in which racialised and gendered framing had positioned him as effective in working with black boys yet at the same time he was being constructed as their mirror image. Whilst David's story may appear ordinary and unremarkable inasmuch as it concerns the dialogue into which beginner teachers are inducted as part of professional learning, it is through these conversations with more experienced colleagues that communities of practice are formed. Moreover, a critical understanding of learning and teaching is a requirement for all teachers in state-maintained schools in England as outlined in the Teachers' Standards (DfE, 2011a). The Standards are a central reference point for professional learning, assessment of pedagogical skills and professional expectations of teachers. There are, nonetheless, important differences here. David's portrayal is illustrative of what Howard (2014) refers to as the shiftless and lazy Black male (pp. 31), a teacher characterised by the "need of control, structure and order" (ibid. pp. 33).

His hypervisibility disturbs the normalised whiteness of the school, his presence is conflictual (for instance, the positive relationships he has with children in his class are in stark contrast with terms which describe him as aggressive, intimidatory and hostile). David is "capable of inducing a state of ontological anxiety" as he "disturbed a particular 'look' (Fanon, 2008; Puwar, 2004). He highlights dissonance in professional relationships, resulting in efforts to manage or contain a perceived threat to the professionalism of teachers in the school (and potentially the safety of the children). In addition to his body being read in racialised ways he is under surveillance (e.g. colleagues have reported to me that he is hostile). To speak is to be aggressive whilst silence conveys unprofessional behaviour. In effect, he is stymied, implicated in the repression of his own resistance. David's body has been marked and reproduced as the raced and gendered 'other'. 


\section{Conclusion}

This paper set out to illustrate processes of racialised and gendered exclusion, othering and surveillance. Although the counternarrative focuses on the experience of one teacher it reveals the complex ways in which racialised and gendered assumptions and stereotypes perpetuate popular tropes about black males. David's story illustrates the careful navigation of one's raced and gendered identity. Through the use of counternarrative we see how black males' movement through normative white spaces are both problematic and problematised - part of a tapestry of recurrent and popular stock stories about black males, which combine to influence how they are constructed and the forms of interaction that take place. David's counter-narrative illustrates transformation from a pupil, student and teacher recasting him as the racialised and gendered other. He does not 'fit'. His otherness is perpetuated through his isolation as a pupil, marginalisation as a student and suspicion as a teacher. He is relationally constructed in and by white education spaces. His raced experience is a process of accretion, a majoritarian tool implemented when convenient to ensure the slow abrasion and erosion of David's identities and to ensure that majoritarian tropes are maintained. Race and gender bind together, they can make sense only in relation to each other.

I have argued that the construction of the black male teacher is influenced by and integrated with wider negative perceptions of black males and that this is inextricably linked to popularised discursive articulations of the presence and experiences of black males in schools. David is inscribed and described by the white education space through daily, mundane, and iterative performances of whiteness. The counternarrative illuminates how white education spaces are implicated in the creation and maintenance of othering, scrutiny and surveillance. Such stories are integral to gaining a more holistic understanding of the issues black male teachers may face. Such depictions "shape public perception, in subtle and not so subtle ways' and are illustrative of "how Black males experience schools and larger society today" (Howard, 2014). Attuned to their position/positioning black male teachers seek to shift the narrative from negative stereotyping to one that focuses on their professional capabilities and skills. In doing so they deploy agentic strategies, including silence as a means through which to navigate white education spaces. However, silence can be misread, its original intent corrupted, rendering its deployment counterproductive and black male teachers mute.

This paper has added to the literature on BME teachers and has shed light on black male teachers' experiences in English schools. It has identified links to the US literature where similar debates are taking place and highlighted black males' hypervisibility. The use of CRT counternarrative has facilitated a more nuanced discussion of these day-to-day encounters in white education spaces. 


\section{Data availability statement}

Research data are not shared.

\section{Ethical guidelines}

Approval for the study was approved by the IOE Ethics Committee. The research adheres to the BERA Ethical Guidelines for Educational Research (2018, $4^{\text {th }}$ edition).

\section{Conflict of interest}

No potential conflict of interest was reported by the author with respect to the research, authorship or publication of this article. 


\section{References}

Allen, R., Bibby, D., Parameshwaran, M., and Nye, P. (2016) Linking ITT and workforce data: (Initial Teacher Training Performance Profiles and School Workforce Census): Research Report. National College for Teaching \& Leadership

BERA (2018) Ethical Guidelines for Research, fourth edition. Last accessed 1.1.2019 https://www.bera.ac.uk/researchers-resources/publications/ethicalguidelines-for-educational-research-2018

Blair, M. (1994) Black Teachers, Black Students and Education Markets. Cambridge Journal of Education, 24 (2): 277-291

Brockenbrough, E. (2015). “The Discipline Stop”: Black Male Teachers and the Politics of Urban School Discipline. Education and Urban Society. 47(5): 499-522

Brown, A. L., and Johnson, M.W. (2014). "Blackness Enclosed: Understanding the Trayvon Martin Incident through the Long History of Black Male Imagery." In (Re)Teaching Trayvon: Education for Racial Justice and Human Freedom, edited by Venus E. Evans-Winters and Magaela C. Bethune, (pp.11-24). Sense.

Brown, K. (2012) On human kinds and role models: a critical discussion about the African American male teacher. Educational Studies: A Journal of the American Educational Studies Association, 48(3): 326-345

Callender, C. (2018) Needles in a haystack: An exploratory study of black male teachers in England. Management in Education, 32 (4): 167-175

Corbin, J., \& Strauss, A. (2015). Basics of Qualitative Research. Thousand Oaks, CA Sage

Crenshaw, K., Gotanda, N., Peller, G., and Thomas, K. (1995) Critical Race Theory: The Key Writings that formed the movement. The New Press

D'amico, D., Pawlewicz, R.J., Earley. P.M, and McGeehan, A.P. (2017) Where Are All the Black Teachers? Discrimination in the Teacher Labor Market. Harvard Educational Review: 87 (1): 26-49.

Delgado, R. (1989). Storytelling for Oppositionists and Others: A Plea for Narrative. Michigan Law Review. 87(8): 2411-2441.

Delgado, R., and Stefancic, J. (2001) Critical Race Theory: An Introduction. New York University Press: New York

Demie, F. (2019). The experience of Black Caribbean pupils in school exclusion in England, Educational Review, DOI: 10.1080/00131911.2019.1590316

DfES (2018) School Teacher Workforce in England: September 2018. https://www.ethnicity-facts-figures.service.gov.uk/workforce-and-business/workforce- 
diversity/school-teacher-workforce/latest\#by-ethnicity-and-gender. Last accessed on 23.10.2019

DfE (2011) A profile of teachers in England from the 2010 School Workforce Census. Research Report DFE-RR151

DfE (2011a) Teachers' Standards: Guidance for school leaders, school staff and governing bodies. Last accessed 30.1.2020

https://assets.publishing.service.gov.uk/government/uploads/system/uploads/attach ment_data/file/665520/Teachers__Standards.pdf

Dixson, A.D. and Rousseau Anderson, C. (2018) Where are We? Critical Race Theory in Education 20 Years Later, Peabody Journal of Education, 93 (1): 121-131

Fanon, F. (2008) Black Skins, White Masks (2nd edition), London: Pluto Press

Foster, T., and Newman, E. (2005). Just a knock back? Identity bruising on the route to becoming a male primary school teacher. Teachers and Teaching: Theory and Practice. 11(4) 341-358.

Gillborn, D. (2006) Critical Race Theory and Education: Racism and anti-racism in educational theory and praxis, Discourse: Studies in the Cultural Politics of Education, 27 (1): 11-32

Gillborn, D. (2005) Education policy as an act of white supremacy: whiteness, critical race theory and education reform, Journal of Education Policy, 20 (4): 485-505

Gillborn, D., Rollock, N., Vincent, C. and Ball, S.J. (2012) 'You got a pass, so what more do you want?': race, class and gender intersections in the educational experiences of the black middle class, Race Ethnicity and Education, 15 (1): 121-139

Glaser, B. G. and Holton, J. (2004) Remodeling Grounded Theory. Forum Qualitative Sozialforschung / Forum: Qualitative Social Research, [S.I.], v. 5, n. 2, May 2004. ISSN 1438-5627. Available at: <http://www.qualitativeresearch.net/index.php/fqs/article/view/607/1315>. Date accessed: 13 Oct. 2019. doi:http: //dx.doi.org/10.17169/fqs-5.2.607.

Griffin, A., \& Tackie, H. (2017). Through our eyes: Perspectives from black teachers. Phi Delta Kappan, 98(5), 36-40.

Haque, Z., and Elliot, S. (2017). Visible and Invisible Barriers: the impact of racism on BME teachers. NUT/Runnymede

Hinds, D. (2019) Education Secretary speaks to leaders of diversity network. https://www.gov.uk/government/speeches/education-secretary-speaks-to-leaders-ofdiversity-network

Howard, T. (2014) Black Male(d): Peril and Promise in the Education of African American Males. New York: Teachers College, Columbia University 
Howard, T. C. and Navarro, O. (2016) 'Critical Race Theory 20 Years Later: Where Do We Go From Here?' Urban Education, 51(3): 253-273

Hylton, K. (2005) Race, Sport and Leisure: Lessons from Critical Race Theory. Leisure Studies, 24(1): 81-98

Jackson, I., Sealey-Ruiz, Y., \& Watson, W. (2014). Reciprocal Love: Mentoring Black and Latino Males Through an Ethos of Care. Urban Education, 49(4), 394-417.

King, J. (2016) The invisible tax on teachers of color. Last accessed 14.10.2019 https://www.washingtonpost.com/opinions/the-invisible-tax-on-blackteachers/2016/05/15/6b7bea06-16f7-11e6-aa55-670cabef46e0_story.html

Kohli, R. (2018). Behind School Doors: The Impact of Hostile Racial Climates on Urban Teachers of Color. Urban Education, 53 (3): 307-333.

Ladson-Billings, G. (2013) Critical Race Theory - What it is Not! In Handbook of Critical Race Theory in Education (eds.) Lynn, M., and Dixson, A. (pp. 34-47). Routledge

Ladson-Billings, G. \& Tate, W. (1995) Toward a critical race theory of education, Teachers College Record, 97(1): 47-68

Ledesma, M. C. and Calderón, D. (2015) 'Critical Race Theory in Education: A Review of Past Literature and a Look to the Future', Qualitative Inquiry, 21(3): 206222

Leonardo, Z. (2009) Race, Whiteness and Education. Oxford, UK: Routledge

Lewis, C.W. (2006) African American male teachers in public schools: An examination of three urban school districts. Teachers College Record, 108(2): 224245.

Lewis, C. W., and Toldson, I. A. (2013) (Eds.) Black Male Teachers: Diversifying the United States' teacher Workforce (Advances in Race and Ethnicity in Education).

Bingley, UK: Emerald

Lynn, M. (2006) Education for the Community: Exploring Culturally Relevant Practices of Black Male Teachers, Teachers College Record, 108 (12): 2497-2522

Lynn, M. (2002) Critical Race Theory and the Perspectives of Black Men Teachers in the Los Angeles Public Schools, Equity \& Excellence in Education, 35 (2):119-130

Martino, W., and Rezai-Rashti, G. (2012) Gender, Race, and the Politics of Role Modelling: The Influence of Male Teachers. Routledge

Matsuda, M.J. (1995) Words that Wound: Critical Race Theory, Assaultive Speech, and the First Amendment. Ethics, 106(1): 211-213 
Maylor, U. (2018) Black male student teachers: tomorrow's teachers? Journal for Multicultural Education, 12(2): 111-125

Maylor, U. (2009) 'They do not relate to people like us': Black teachers as role models for Black pupils, Journal of Education Policy, 24 (1): 1-21.

Miller, P.W. (2018) Overseas trained teachers (OTTs) in England: Surviving or thriving? Management in Education, 32(4): 160-166

Miller, P., and Callender, C. (2018) Black Leaders Matter: Agency, Progression and Sustainability of BME School Leadership in England. Journal for Multicultural Education, 12 (2): 183-196.

NASUWT (2017) Visible Minorities, Invisible Teachers: BME Teachers in the Education System in England. NASUWT/Runnymede

National Education Union (2019) Capability. Last accessed 14 ${ }^{\text {th }}$ October 2019. https://neu.org.uk/advice/capability

National Union of Teachers (2017) Visible and Invisible Barriers: The Impact of Racism on BME Teachers. NUT/Runnymede

Office for National Statistics (ONS), Social Survey Division. (2019). Annual Population Survey, July 2017 - June 2018. [data collection]. 3rd Edition. UK Data Service. SN: 8415, http:// doi.org/10.5255/UKDA-SN-8415-4

Ogunbawo, D. (2012). Developing Black and Minority Ethnic Leaders: The Case for Customized Programmes. Educational Management Administration \& Leadership, 40(2), 158-174.

Pabon, A. (2016) Waiting for Black Superman: A Look at a Problematic Assumption. Urban Education, 51 (8): 915-939

Pilkington, A. (2014) The Sheer Weight of Whiteness in the Academy: A UK Case Study. In Race, R., and Lander, V. (eds) Advancing Race and Ethnicity in Education (pp. 193-209). Palgrave Macmillan

Puwar, N. (2004) Space Invaders: Race, Gender and Bodies Out of Place. Berg

Read, B., Burke. P.J. and Crozier, G. (2018) 'It is like school sometimes': friendship and sociality on university campuses and patterns of social inequality, Discourse: Studies in the Cultural Politics of Education, DOI: 10.1080/01596306.2018.1457626

Rhodes, D. (2017) Schools need 68,000 extra BME teachers to reflect population. BBC News. http://www.bbc.co.uk/news/uk-england-40568987 last accessed 14th May 2018

Rollock, N. (2012) Unspoken rules of engagement: navigating racial microaggressions in the academic terrain, International Journal of Qualitative Studies in Education, 25(5): 517-532 
Solórzano, D. \& Delgado Bernal, D. (2001) Critical race theory, transformational resistance and social justice: Chicana and Chicano students in an urban context, Urban Education, 36: 308-342

Solórzano, D. G. and Yosso, T. J. (2002) 'Critical Race Methodology: CounterStorytelling as an Analytical Framework for Education Research', Qualitative Inquiry, 8(1), pp. 23-44

Steel, S. (2015) Race to the Top 2: Diversity in Education. Elevation Networks. Last accessed 31 ${ }^{\text {st }}$ December 2018. file:///C:/Users/User/Downloads/Race-to-The-Top-2Diversity-In-Education1.pdf

Stovall, D. (2006) Where the rubber hits the road: CRT goes to high school. In A. Dixson and C. Rousseau (.) Critical Race Theory in Education: All God's Children Got a Song, pp. 231-240. Routledge

Stovall, D. (2005) Critical Race Theory as Educational Protest: Power and Praxis. In Black Protest Thought and Education (ed) W. Watkins (pp. 197-211). Peter Lang

Strand, S. (2012) The White British-Black Caribbean achievement gap: tests, tiers and teacher expectations, British Educational Research Journal, 38(1): 75-101

Thomas, E. E., and Warren, C. A. (2017). Making it relevant: how a black male teacher sustained professional relationships through culturally responsive discourse, Race Ethnicity and Education. 20 (1): 87-100

U.S. Department of Education. (2016). The state of racial diversity in the educator workforce. Retrieved from https://www2.ed.gov/rschstat/eval/highered/racialdiversity/state-racial-diversityworkforce.pdf

Warmington, P. (2019) Critical Race Theory in England: Impact and Opposition. Identities: Global Studies in Culture and Power, DOI: 10.1080/1070289X.2019.1587907

Woodson, A., and Pabon, A. (2016) "I'm None of the Above: Exploring themes of heteropatriarchy in the life histories of Black male educators." Equity and Excellence in Education, 49 (1): 57-71

Yancy, G. (2014) Introduction: White Crisis and the Value of Losing One's Way in Exploring Race in Predominantly White Classrooms, in Yancy. G., and M del Guadalupe Davidson, (eds) Exploring Race in Predominantly White Classrooms: Scholars of Colour Reflect. (pp.1 - 16). Routledge

Yancy, G. (2008) Black Bodies, White Gazes: The Continuing Significance of Race. Rowman and Littlefield 
